International Journal of Clinical Pharmacology \& Toxicology (IJCPT)

ISSN 2167-910X

\title{
Pharmacological and Toxicological Effects of Chemotherapy on Cancer Patients in This Era and The Role of Open Access Journals in This Matter
}

Bassam Abdul Rasool Hassan*

Clinical Pharmacy Discipline, School of Pharmaceutical Sciences, University of Sains Malaysia, 11800, Minden, Penang, Malaysia.

\section{*Corresponding Author:}

Bassam Abdul Rasool Hassan,

Clinical Pharmacy Discipline, School of Pharmaceutical Sciences, University of Sains Malaysia, 11800, Minden, Penang, Malaysia.

Tel: (+6)016-423-0950

E-mail: bassamsunny@yahoo.com

Received: June 01, 2012

Published: October 01, 2012

Citation: Bassam Abdul Rasool Hassan (2012) Pharmacological and Toxicological Effects of Chemotherapy on Cancer Patients in This Era and The Role of Open Access Journals in This Matter. Int J Clin Pharmacol Toxicol. 1(3e), 1. doi: http://dx.doi.org/10.19070/2167-910X$120003 \mathrm{e}$

Copyright: (C) 2012 Bassam Abdul Rasool Hassan. This is an openaccess article distributed under the terms of the Creative Commons Attribution License, which permits unrestricted use, distribution and reproduction in any medium, provided the original author and source are credited.

\section{Chemotherapy Background}

Chemotherapy was developed and used since the Word War I from the chemical weapon program of the United State of America (USA). Since then chemotherapy has became as one of the most important and significant treatment of cancer. Its main mechanism of action is by destroying the cancer cells which are characterized by their high multiplication and growth speed [1,2]. However when comparing chemotherapy with other types of treatments, it still remain potentially high risk with many side effects which are difficult to manage. Chemotherapy used required the involvement of various clinical professionals during its various stages of administration and enormous patient health care is needed to overcome its side effects $[1,3]$.

\section{Open Access Journal Role in This Matter}

Open access journals specifically (International Journal of Clinical Pharmacology \& Toxicology) will play a very important role in developing exchange and sharing of experience between clinical staff and this will mainly leads to knowledge grows up. And this is the main objective for each research conducted in the medical field [4]. Therefore open access journals role consider very important specifically in this point.

\section{Conclusion}

Open access journal consider as a constructive way in exchange the knowledge related with chemotherapy pharmacological and toxicological effect in cancer treatment. Therefore, Open Access Journals play as a very supportive role in this matter i.e., by increasing knowledge exchange.

\section{References}

[1]. WEIR-HUGHES, D. (2005) Foreword. IN BRIGHTON, D., \& WOOD, M. (Ed.) The Royal Marsden Hospital Handbook of Cancer Chemotherapy. London Elsevier / Churchill Livingstone.

[2]. KELLAND, L. R. (2005) Cancer cell biology, drug action and resistance. IN BRIGHTON, D., \& WOOD, M. (Ed.) The Royal Marsden Hospital Handbook of Cancer Chemotherapy London, Elsevier / Churchill Livingstone

[3]. RIZZO, T., \& CLOOS, R., (2002) Chemotherapy. IN THACKERY, E. (Ed.) The Gale Encyclopedia of Cancer Detroit, Gale Group.

[4]. Daniel (2008) Open Access is an important step on the way towards open science. World Association of Young Scientists. 